\title{
Correlação entre os fatores inerentes à produção de frangos de corte versus emissão de amônia
}

\author{
Bruna C. S. Lima (EM), Daniella J. de Moura (Orientador), Thayla M. R. de Carvalho Curi (PQ), Rimena \\ do A. Vercellino (PG).
}

\section{Resumo}

O presente trabalho objetivou compreender quais fatores relacionados à produção de frangos de corte possuem maior ou menor contribuição para a produção e emissão de amônia durante a criação de um lote das aves e quais ações mitigadoras podem ser levadas em consideração visando a diminuição deste poluente. Para isso, dados como temperatura, umidade relativa, $\mathrm{pH}$ e umidade da cama, concentração de amônia, velocidade do ar e dados zootécnicos dos animais foram monitorados durante um ciclo de produção (1 aos 42 dias de idade das aves). Com os dados de concentração de amônia e velocidade do ar será calculada a taxa de emissão. Após, será realizada uma análise de correlação entre a taxa de emissão com as demais variáveis coletadas para verificar quais desses fatores possuem maior ou menor influência na emissão deste poluente.

Palavras Chave: Ambiência, Avicultura, Bem-estar animal.

\section{Introdução}

O objetivo deste estudo foi de correlacionar as variáveis que são comumente estudadas na produção de frangos de corte (temperatura, velocidade do ar, concentrações de amônia, condições da cama e o desempenho zootécnico das aves) com a emissão de amônia oriunda dessa produção. Além de iniciar a bolsista nas atividades científicas do grupo de pesquisa.

\section{Resultados e Discussão}

O presente projeto sofreu atrasos em sua realização. No entanto, a bolsista acompanhou toda a montagem e planejamento do experimento. Para efetiva iniciação da bolsista na ciência e na área acadêmica foram realizadas as seguintes atividades:

Desenvolvimento da revisão bibliográfica de assuntos relacionados ao projeto. Os assuntos estudados foram:

"Construções rurais e ambiência", "Bem-estar animal", "Engenharia Agrícola", "Ambiência de instalações de frangos de corte, poedeiras, suínos e bovinos de corte", "Zootecnia de Precisão", "Qualidade do ambiente aéreo", "Equipamentos utilizados na criação animal".

Houve a participação em aulas da graduação da Profa. Dra. Daniella Jorge de Moura na disciplina FA 473 - Sistema de Produção.

Participação no Workshop de Ambiência na Produção Avícola realizado no anfiteatro da Faculdade de Engenharia Agrícola.

Apresentação de 4 painéis com assuntos diversos pesquisados para complementação da revisão bibliográfica:
"Construções rurais e ambiência"; "Sistema de produção de frangos de corte: conceitos básicos de criação"; "Poedeiras: produção e ambiência"

"Produção de codornas".

Visita às bibliotecas da Unicamp para conhecimento do seu funcionamento, pesquisa no catálogo eletrônico de livros e teses, e empréstimo dos livros. Também foi realizada pesquisas em bases de dados virtuais: "Scielo", "Science Direct" e "Google Acadêmico".

Acompanhamento do experimento na câmara de preferência animal, bem como treinamento do uso da câmara termográfica.

Participação no "Workshop Internacional de Ambiência de Precisão" como também na aula de pós-graduação ministrada pela palestrante Dra. Tami Brown-Brandl.

Sendo assim, o cronograma foi executado de acordo com o planejado em relação às atividades previstas.

\section{Conclusões}

As atividades realizadas permitiram que a bolsista alcançasse efetivo avanço no seu perfil científico, detectando melhoras sensíveis na pesquisa de revisão bibliográfica, apresentação oral e delineamento e montagem de experimentos.

\section{Agradecimentos}

Ao CNPq pela bolsa.

${ }^{1}$ GLOBALG.A.P. Integrated Farm Assurance / Poultry.. PY 5.4: 2011-2012, 2012. Disponível em <www.globalgap.org > ${ }^{2}$ Manning, L.; Chadd, S.A.; Baines, R.N. Poul. Sc. 2007, 63, 63-68. ${ }^{3}$ Curtis, S.E. The Iowa State University: Ames, 1983, 410p. 